\title{
Okul öncesi dönemdeki çocukların model alma becerileri gelişimlerinin incelenmesi
}

\section{The Analysis of preschool children' pattern skill development}

\author{
Meryem Çelik ${ }^{1}$
}

\begin{abstract}
Makale Geçmişi
Geliş : 17 Nisan 2019

Düzeltme : 5 Şubat 2020

Kabul : 3 Nisan 2020
\end{abstract}

Makale Türü

Arastırma Makalesi

\section{Article History}

Received : 17 April 2019

Revised : 5 February 2020

Accepted : 3 April 2020

\section{Article Type}

Research Article

\begin{abstract}
Öz: Matematik, modellerin dilidir ve bilimidir. Bir model, aynı sırada veya düzende sürekli tekrar eden sayıların, renklerin, nesnelerin, şekillerin veya eylemlerin ardışıklı̆̆ıdır. Model alma çocuklarda matematiksel fikirlerin, ilişkilerin soyutlanması ve akıl yürütmenin gelişmesi için önemlidir. $\mathrm{Bu}$ çalıșmanın amacı, çocukların model alma beceri gelișimlerinin, incelenmesidir. Araștırma ilișkisel tarama modeline göre yürütülmüştür. Araştırmada amaçlı örneklem belirleme yöntemi kullanılmıştır. Çalışma grubu anaokuluna devam eden 182 çocuktan oluşmuştur. Veri toplama aracı olarak, araştırmacı tarafından geliştirilen ölçme aracı kullanılmıştır. Araştırmanın verileri 2016-2017 eğitim-öğretim yılının Mayıs ayında toplanmıștır. Elde edilen verilerin yüzde, frekans değerleri hesaplanmıștır. Ayrıca gruplar arası farklılıkları ve değişkenler arası ilişkileri ölçmek amacı ile Mann-Whitney-U testi ve Kruskal-Wallis test analizleri yapılmışır. Araştırma sonuçları çocukların model alma beceri gelişimlerinde cinsiyete göre anlamlı bir fark olmadığını göstermiştir. Bununla beraber, model alma beceri gelişimleri ve çocukların yaş1, eğitim kurumuna devam etme süresi, anne-babanın eğitim düzeyi ve ailenin ekonomik düzeyi değişkenleri arasında anlamlı fark olduğu tespit edilmiştir.
\end{abstract}

Anahtar Kelimeler: Model alma, Çocuk, Matematik

Abstract: Math is the language of patterns and science. One pattern is the sequence of numbers , objects, shapes, colours and practices that replicate continuingly in same order and system. Pattern is urgent to children for developing their mathematical ideas, isolating connection end resoning. The target of that study is to analyze preschool children' pattern skill development. The research was designed in descriptive survey model. and purposeful sampling were used. The working group consisted of 182 children who still go to a kindergarden. The measuring tool was developed by a researcher has been used as a data collecting tool. The data were collected during 2016-2017 educational year in May. The obtained data was interpted by percentageand frequency. In addition of Mann-Whitney-U test and Kruskal-Wallis test were used to measure differences in groups and relations among variations. The result of that research showed that there was no meaningful difference of sex in children's pattern skill development. However there was a meaningful difference among children's pattern skill development by their ages, the period they go to an educational institution, their parents' educational attainment and economic conditions.

Key Word: Pattern, Child, Math

DOI: $10.24130 /$ eccd-jecs.1967202042143

\footnotetext{
${ }^{1}$ Düzce Üniversitesi, Eğitim Fakültesi, Temel Eğitim Bölüm, meryemcelik@duzce.edu.tr, ORCID: https://orcid.org/0000-0002-5724-8109
} 


\section{SUMMARY}

\section{Introduction}

This study was carried out to examine the pattern skills development of the 4-5 year old children who attend preschool education. When the studies which are related to preschool children's math skills were viewed, it's seen that numbers-operations, geometric shapes, validity-reliability studies, test development studies, mathematics development of children and relationship with several variables, mathematics self-efficacy of teachers, mathematics belief and attitudes for math were discussed. It is remarkable that there are few studies researching children' pattern skills development. It is thought that analyzing the pattern skills development of children in terms of some variables will contribute to this field and it'll be considered beneficial for researches and teachers.

\section{Method}

The study was designed in descriptive survey model. The target population of the study consists of 4-5 year old children attending preschools in Ministry of National Education in Akçakale county center of Şanliurfa province. The sample of the study comprised of 182 children from 3 preschools. In the research, "General Information Form" was used to collect general information about children and their families. In General Information Form, the questions take place about the birth date, gender, preschool education status, the education level and the working status of the parents, and the monthly income of the family of the child included in the sample. To evaluate the pattern skills development of the preschool children, the assessment and evaluation instrument developed by the researcher was used. This evaluation tool is in the form of worksheet 1, which evaluates the continuation of ababa (red blue red blue), aabbaabb (blue blue red red blue blue red red) patterns of children, and in the form of worksheet 2, which assesses children' aabaab (blue blue red blue blue red), abc (green blue red green blue red) and create their own patterns and continuation.

The data of the study were collected in May 2017. The worksheets were given to the classroom teachers of 4-5-year-old children studying in preschool in a prepared way. Under the supervision of the researcher, the teachers seat the students in a way not to be affected by each other and applied the worksheet 1 which the child's name was written and the worksheet 2 was applied to the same children 2-3 days later. The same instructions were given to the children and there was no intervention in any way.

\section{Results}

When looking at the results of the percentage of 4-5 year old children' pattern skills development, it was seen that the percentage of the 5 year old children' is higher. In both groups, the pattern skills development was as $\mathrm{AB}, \mathrm{AABB}, \mathrm{AAB}, \mathrm{ABC}$ in an order and it's observed that the percentage towards creating its own model has decreased. It was viewed that there was no significant difference in pattern skills development of 
children according to gender. Also, the pattern skills development of children differed in terms of the duration of attendance of preschool education institution $\left[\chi^{2}(4)=30,394, p<0.05\right]$. It was observed that the pattern skills development of children differentiate based on the income level of families $\left[\chi^{2}(4)=101.490\right.$, $\mathrm{p}<0.05]$. It was seen that the pattern skills development of children change according to the education level of parents $\left[\chi^{2}(4)=21,582, \chi^{2}(4)=15,514, \mathrm{p}<0.05\right]$.

\section{Conclusion and Disscussion}

It can be said that in pattern skills development, the children aged 5 years are more successful than 4 years old. As a similar result Fyfea, Evans, Matz, Hunt and Alibali (2017) studied the performance of children (n:36) in three types of pattern skills developmen with various difficulties. In the study findings, it was found that the children who were elder were more successful than the younger ones. It was observed that girls and boys have the same level of success in pattern skills development. Collins and Laskin's (2015) study with 66 children who were in pre-school period supported the finding that there was no difference in terms of gender in the pattern skills development of children. It was observed that the pattern skills development of the children increased as the time to attend the pre-school education institution raised. Papic, Mulligan \& Mitchelmore (2011) in their study, pointed out that even children who were not enrolled in a program from a pre-school were successful in creating complex patterns if they had the living opportunity to develop math skills. It can be said that there was an increase in the pattern skills development of children as the income level of the family raises. Klein \& Starkey (2004) applied a pattern skills development question to the 4-5 years old child in their study, and it was found out that children with medium income had higher levels of success than low income children. It can be mentioned that as long as the level of education of the parents rises, the pattern skills development of the children increase. The education level of the family influences the perspectives and attitudes of mathematics and the quality of the mathematical activities offered to children at home (Clements \& Sarama, 2007; Musun-Miller \& BlevinsKnabe, 1998). 


\section{GİRİŞ}

Model alma matematik ve matematik eğitiminin temelidir (Watters, 2004; Pessia, Tirosh, Levenson, Barkai \& Tabach, 2017). Copley (2000), 'Matematik, modellerin dilidir ve bilimidir. Modeller hakkında düşünmek çocukların matematiği anlamalarına yardım eder' demektedir (Jackman, 2005). Günümüzde yurtdışında yapılan birçok araştırma matematik başarısı ile model alma becerisi arasındaki ilişkiyi ortaya koymuştur (Kidd et al., 2014; Rittle-Johnson, Fyfe, Hofer, \& Farran, 2016). Bir model, aynı sırada veya düzende sürekli tekrar eden sayıların, renklerin, nesnelerin, şekillerin veya eylemlerin ardışılı̆̆ıdır. Model alma çocuklarda matematiksel fikirlerin, ilişkilerin soyutlanması ve akıl yürütmenin gelişmesi için önemlidir (Papic \& Mulligan, 2005). Model alma ile çocuklar karmaşık olaylardaki matematiksel yapıları fark ederler. Çünkü model alma olayların yüzeysel (biyolojik, fiziksel yada sanatsal) özelliklerden ziyade yapısal (elementler arası etkileşimler ve ilişkiler) özelliklerine odaklanmaktadır. Bu özelliği ile matematiksel model alma, biyoteknoloji, havacılık mühendisliği ve bilişim gibi alanlarda modern bilimsel araştırmaların temelini oluşturur (English \& Watters, 2005).

Modeller cebirsel düşünmenin köşe taşları olarak görev yaparlar. Modelleri hatırlama, tanımlama, genişletme ve çevirme çocukları cebirde problem çözme ve soyut düşünmeye becerilerinin gelişiminde etkili bir rol oynar. Çocukların modelleri görme ve yaratma yeteneği, ilişkileri görmeyi, bağlantıları bulmayı, genelleme yapmayı ve tahminlerde bulunmayı öğrenmelerini destekler. Böylece model oluşturma çocukların kendi dünyalarındaki düzeni görmelerini sağlar (Seefeldt, 2005; Jakman, 2005).

Çocuklarda model alma beceri gelişimi okul öncesi dönemden itibaren aşamalı bir şekilde olmaktadır. İlgili alan yazınında tekrarlayan modeller, genişleyen modeller ve ilişki modelleri olarak genel model türleri yer almaktadır (Sperry Smith, 1996; Akman, 2012). Okul öncesi dönemde özellikle tekrarlayan modeller üzerinde durulmaktadır (Tsamir, Tirosh, Levenson, Barkai and Tabach, 2017). Tekrarlayan modellerde "tekrar birimi” olarak adlandırılan temel öğeler tekrarlanır (Zazkis \& Liljedahl, 2002). Bu tekrar birimi kolaydan zora AB,AABB,AAB,ABC ve daha karmaşık çeşitleri olarak sıralanabilir. Çocukların modelleri keşfetmeleri ise dört aşamada gerçekleşmektedir. Bunlar şöyledir: Çocuk modelin farkına varır, modeli açıklar, modeli devam ettirir ve son aşamada kendi modelini oluşturur (Sperry Smith, 1996).

Çocukların model alma gelişimlerinin diğer matematik gelişimleri gibi okul öncesi dönemden itibaren öğretim uygulamaları ile desteklenmesi gerekmektedir. Bu yüzden model alma ulusal ve uluslararası okul öncesi eğitim programları içerisinde yerini almıştır (MEB. 2013; ACARA, 2010; Depps, 2001; NCTM, 2000). 
Türkiye'de okul öncesi dönem çocukların matematik becerileri ile ilgili yapılan çalışmalar incelendiğinde; sayılar-işlemler, geometrik şekiller, geçerlik-güvenirlik çalışmaları, test geliştirme çalışmaları, çocuklarda matematik gelişimi ve çeşitli değişkenler ile ilişkisi, öğretmenlerin matematik özyeterliği, matematik inancı, matematiğe karşı tutumlarının ele alındığı görülmektedir (Aktaş Arnas, Deretarla Gül, \& Sığırtmaç, 2003; Aslan, \& Aktaş Arnas, 2007; Bolat, \& Sığırtmaç, 2006; Bulut, \& Tarım, 2006; Çelik, 2017a, Çelik, 2017b, , Erdoğan, \& Baran, 2006; Taştepe, \& Temel, 2013; Avc1, 2015; Yılmaz, 2015; Pekince \& Dağlığlu, 2017). Çocukların model alma becerilerini inceleyen çalışmaların az olduğu dikkati çekmektedir. Çocukların model alma becerilerinin incelenmesinin bu alana katkı sağlayacağı, araştırmacıların çocukların model alma becerilerini daha fazla inceleyeceği ve öğretmenlerinde çocukların model alma becerilerini daha sistematik şekilde desteklemelerine dikkat çekeceği için yararlı olacağı düşünülmektedir.

\section{Amaç}

Bu çalışma okul öncesi eğitim kurumuna devam eden 4-5 yaş grubu çocukların model alma beceri gelişimlerini incelemek amacıyla yapılmıştır. Bu amaç doğrultusunda çalışmada aşağıdaki araştırma sorularına cevap aranmıştır:

- 4-6 yaş çocukların model alma becerileri ne düzeydedir?

- 4-6 yaş çocukların model alma becerileri cinsiyete göre anlamlı bir şekilde farklılaşmakta midir?

- 4-6 yaş çocukların model alma becerileri yaşa göre anlamlı bir şekilde farklılaşmakta mıdır?

- 4-6 yaş çocukların model alama becerileri okul öncesi eğitime devam etme sürelerine göre anlamlı bir şekilde farklılaşmakta mıdır?

- 4-6 yaş çocukların model alama becerileri ailelerinin gelir düzeyine göre anlamlı bir şekilde farklılaşmakta mıdır?

- 4-6 yaş çocukların model alma becerileri anne-babanın eğitim durumuna göre anlamlı bir şekilde farklılaşmakta mıdır?

\section{YÖNTEM}

\section{Araştırmanın Modeli}

Çalışma, nicel araştırmalardan betimleyici ilişkisel tarama modelindedir. İlişkisel tarama modeli, iki ve daha çok sayıdaki değişken arasında birlikte değişim varlığını ve/veya derecesini belirlemeyi amaçlamaktadır (Karasar, 2005). Bu araştırma kapsamında çalışmaya katılan çocukların model alma 
becerileri okul öncesi dönem çocuklarının model alma beceri gelişimlerini ölçen form kullanılarak belirlenmiştir.

\section{Araştırmanın Örneklemi}

Çalışmanın evrenini, Şanlıurfa ili Akçakale ilçe merkezinde Milli Eğitim Bakanlı̆̆ı'na bağlı anaokullarına devam eden 4-5 yaş çocukları oluşturmaktadır. Araştırmanın örneklemini seçilen 3 anaokulundan toplam 182 çocuk oluşturmaktadır. Örneklemin belirlenmesinde "Kolay ulaşılabilir durum örneklemesi” kullanılmıştır. Bu yöntemde, araştırmacı kendine ulaşılması yakın durumu seçer (Yıldırım ve Şimşek, 2005). Bu nedenle, araştırmacı kendisinin kolay ulaşabildiği okulları seçmiştir. Araştırmaya katılan çocukların \% 51.6'sı 4 yaşında ve \%48.4 5 yaşındadır ve \%56's1 7-12 aydır okul öncesi eğitim kurumuna devam etmektedir. Çocukların %51.6’sı kız ve \%48.4'i erkektir. Bu çocukların annelerinin \%35.7'si ilk ve ortaokul mezunu, \%20.9’u okuryazar değildir. Çocukların babalarının \%42.9'u lise ve \%29.7'si ilk ve ortaokul mezunudur. Annelerin \%92.9' ev hanımı, babaların \%31.3’ü serbest mesleğe sahiptir. Ailelerin \%32.4’ü çok düşük ve \%29.7’si orta ekonomik düzeye sahiptir.

\section{Veri Toplama Araçları}

Araştırmada, çocuklar ve ailelerine ilişkin genel bilgileri toplamak amacıyla "Genel Bilgi Formu" kullanılmıştır. Genel Bilgi Formu'nda örnekleme dahil edilen çocuğun doğum tarihi, cinsiyeti, okul öncesi eğitim kurumuna gitme durumu, anne-babanın öğrenim durumu, anne-babanın çalışma durumu ve ailenin aylık geliri ile ilgili sorular yer almaktadır. Okul öncesi dönem çocukların model alma beceri gelişimlerini değerlendirmek için araştırmacı tarafından geliştirilen ölçme aracı kullanılmıştır. Bu ölçme aracı çocukların abab (kırmızı mavi kırmızı mavi), aabbaabb (mavi mavi kırmızıkırmızı mavi mavi kırmızı kırmızı) modellerrini devam etmesini değerlendiren çalışma yaprağı 1 ve aabaab (mavi mavi kırmızı mavi mavi kırmızı), abc (yeşil mavi kırmızı yeşil mavi kırmızı) ve kendi modellerini oluşturup devam etmesini değerlendiren çalışma yaprağ 2 şeklindedir.

\section{Ölçme Aracının Geçerlik ve Güvenirliğine ilişkin Bilgiler}

Ölçme aracında yer alan modellerin uygulama yönergelerinin ve değerlendirme ölçütlerinin kapsam geçerliliği için üç uzmanın görüşüne sunulmuştur. Uzmanlar bir değişikliğe gerek görmemiştir. Diğer bir aşamada yapı-kavram geçerliği (construct validity) gerçekleștirilmiştir. Çalışma sayfalarının ölçülmek istenen davranış bağlamında soyut bir kavramı doğru bir şekilde ölçebilme derecesini belirleyebilmek (Büyüköztürk 2004, McLoughlin ve Lewis 2005) amaciyla, okul öncesi eğitim kurumuna devam eden 4-5 yaş grubu 15 çocukla çalışma sayfalarının pilot uygulaması tamamlanmıştır. Pilot uygulama sonrasında herhangi bir değişikliğe gerek görülmemiş 
ve çalışma sayfaları asıl uygulamada kullanılmıştır. Pilot uygulama sonucunda çalışma sayfalarında değişiklik yapılmadığından pilot çalışmaya alınan 10 çocuk örneklem grubuna dahil edilmiştir. Araştırmanın güvenirlik çalışması için KR-20 (Kudher Richardson-20) analizi kullanılmıştır. KR20 formülünün uygulanabilmesi için veriler 0 ve 1 şeklinde kodlanmalıdır. Yapılan güvenirlik analizi sonucunda KR-20=0.82 olarak bulunmuştur. Güvenirlik katsayısının .70 ve daha yüksek olmas1 test puanlarının güvenirliği için genel olarak yeterli görülmektedir (Büyüköztürk, 2004).

\section{Verilerin Toplanmas1}

Araştırmanın verileri 2017 yılı Mayıs ayında toplanmıştır. Okul öncesi eğitim kurumuna devam eden 4-5 yaş çocukların sınıf öğretmenlerine çalışma sayfaları verilmiştir. Araştırmacının gözetiminde öğretmenler, çocukları birbirlerinden etkilenmelerini önleyecek bir düzende sınıfta oturtmuş ve çocuğun isminin yazılı olduğu çalışma sayfası 1'i ve 2-3 gün sonra çalışma sayfası 2'yi aynı çocuklara uygulanmıştır. Çocuklara aynı yönergeler verilmiş ve hiçbir şekilde müdahale edilmemiştir.

\section{Verilerin Analizi}

Araştırmanın amacına yönelik toplanan veriler değerlendirilerek istatistiksel analizler yapılmıştır. Araştırmaya dahil edilen çocukların puanları kayıt formuna kaydedilmiştir. Kayıt formundaki bilgiler bilgisayar ortamına aktarılarak yüzdelik oranları hesaplanmışır. Değisskenler arasındaki farklılıklar mann-whitney-u testi ve kruskal-wallis testi ile analiz edilmiştir.

\section{BULGULAR}

Model oluşturmada çocukların yaş ve model zorluğuna göre modeli devam ettirme ile yeni model oluşturma beceri gelişimleri düzeyi yüzdelik oranları aşağıdaki şekilde sunulmaktadır.

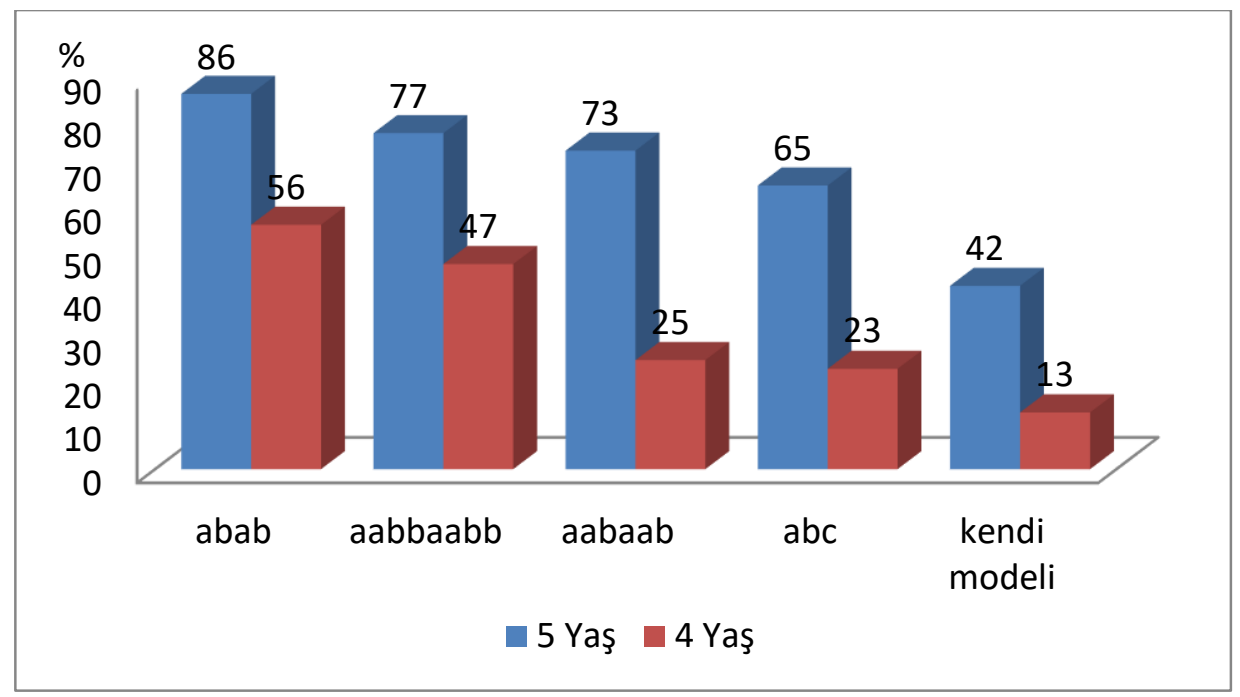

Şekil 1: 4-5 yaş çocukların model oluşturma beceri gelişimleri yüzdelik oranları sonuçları 
Şekil 1 incelendiğinde 5 yaş çocukların model oluşturma beceri gelişimleri yüzdelerinin 4 yaş çocuklardan yüksek olduğu görülmektedir. Her iki grupta da model oluşturma becerilerinin kolaydan zora doğru sıra ile $\mathrm{AB}, \mathrm{AABB}, \mathrm{AAB}, \mathrm{ABC}$ ve kendi modelini oluşturmaya doğru yüzdelik oranlarının düştüğü görülmektedir.

4-6 yaş çocukların model alma becerileri gelişimin cinsiyete göre anlamlı bir şekilde farklılaşma olup olmadığı mann-whitney-u test analiz sonuçları Tablo 1'de verilmiştir.

Tablo 1: Çocukların model alma beceri gelişiminin cinsiyete göre mann-whitney-u testi sonuçları

\begin{tabular}{llccccc}
\hline & \multicolumn{1}{c}{ Grup } & n & S1ra Ort. & S1ra Top. & U & p \\
\cline { 2 - 7 } & k1z & 94 & 87,89 & 8262 & 3797 & .331 \\
& Erkek & 88 & 95,35 & 8391 & & \\
& Toplam & 182 & & & & \\
\hline $\mathrm{p}>$.05 & & & & & &
\end{tabular}

Tablo 1'de çocukların model alma beceri gelişimlerinde cinsiyet durumuna göre anlamlı bir farklılığın olmadığ1 görülmektedir [ U=3797, p> 0.05].

4-6 yaş çocukların model alma becerileri gelişimin yaş durumuna göre anlamlı bir şekilde farklılaşma olup olmadığı mann-whitney-u test analiz sonuçları Tablo 2'de verilmiştir.

Tablo 2: Çocukların model alma beceri gelişiminin yaş durumuna göre mann-whitney-u testi sonuçları

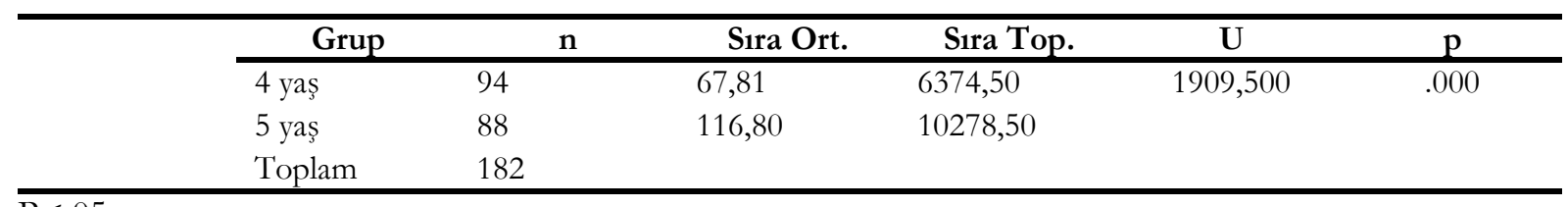

$\overline{\mathrm{P}<.05}$

Tablo 2'de çocukların model alma beceri gelişimlerinde yaş durumuna göre 5 yaş grubu çocukların anlamlı düzeyde pozitif yönde farklı oldukları bulunmuştur. [ $\mathrm{U}=1909,500, \mathrm{p}<0.05$ ]. 4-6 yaş çocukların model alma becerileri gelişimin yaş durumuna göre anlamlı bir şekilde farklılaşma olup olmadığı kruskal-wallis test analiz sonuçları Tablo 3'de verilmiştir.

Tablo 3: Çocukların model alma beceri gelişiminin okul öncesi eğitim kurumuna devam etme süresine göre kruskal-wallis testi sonuçları

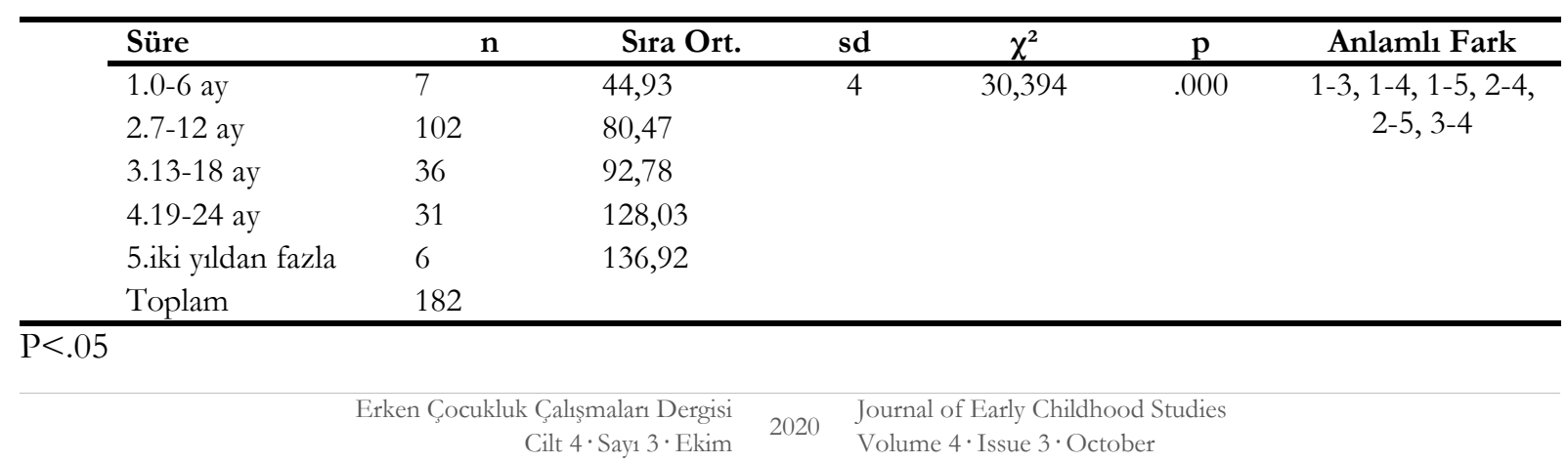


Tablo 3 incelendiğinde çocukların model alma beceri gelişiminin okul öncesi eğitim kurumuna devam etme süresine göre farklılaştığı görülmektedir $\left[\chi^{2}(4)=30,394, p<0.05\right]$. Oluşan bu farklılaşmanın hangi süreler arasında olduğunu tespit etmek için yapılan Mann Whitney U testi sonuçlarına göre; iki yıldan fazla okul öncesi eğitim kurumuna devam eden çocukların 0-6 ay ve 712 ay devam eden çocuklarından, 19-24 ay devam eden çocukların 7-12 ay ve 13-18 ay devam eden çocuklardan ve 13-18 ay devam eden çocuklarında ayrıca 0-6 ay devam eden çocuklardan anlamlı düzeyde pozitif yönde farklı oldukları bulunmuştur.

4-6 yaş çocukların model alma becerileri gelişimin ailenin gelir durumuna göre anlamlı bir şekilde farklılaşma olup olmadığı kruskal-wallis test analiz sonuçları Tablo 4'de verilmiştir.

Tablo 4: Çocukların model alma beceri gelişiminin ailenin gelir durumuna göre kruskal-wallis testi sonuçları

\begin{tabular}{|c|c|c|c|c|c|c|}
\hline Düzey & $\mathbf{n}$ & Sira Ort. & sd & $\chi^{2}$ & $\mathrm{p}$ & Anlamli Fark \\
\hline 1.Çok Düşük & 59 & 44,40 & 4 & 101.490 & .000 & $1-3,1-2,1-4,1-5$ \\
\hline 2.Düşük & 53 & 86,38 & & & & $2-3,2-4,2-5,3-5$ \\
\hline 3.Orta & 54 & 131,30 & & & & \\
\hline 4.İyi & 6 & 129,58 & & & & \\
\hline 5.Çok İyi & 10 & 158,80 & & & & \\
\hline Toplam & 182 & & & & & \\
\hline
\end{tabular}

Tablo 4 incelendiğinde çocukların model alma beceri gelişiminin ailelerin gelir durumuna göre farklılaştığı görülmektedir $\left[\chi^{2}(4)=101.490, \mathrm{p}<0.05\right]$. Oluşan bu farklılaşmanın hangi gelir düzeyleri arasında olduğunu tespit etmek için yapılan Mann Whitney U testi sonuçlarına göre; düşük, orta, yüksek ve çok yüksek gelire sahip olan ailelerin çocukları çok düşük gelire sahip olan ailelerin çocuklarından, orta gelire sahip olan ailelerin çocukları yine düşük gelire sahip ailelerin çocuklarından, iyi gelir düzeyine sahip ailelerin çocukları düşük gelir düzeyine sahip ailelerin çocuklarından ve çok yüksek gelire sahip olan ailelerin çocukları düşük, orta gelire sahip olan ailelerin çocuklarından anlamlı düzeyde pozitif yönde farklı oldukları bulunmuştur.

4-6 yaş çocukların model alma becerileri gelişimin anne ve babanın eğitim durumuna göre anlamlı bir şekilde farklılaşma olup olmadığı kruskal-wallis test analiz sonuçları Tablo 5'de verilmiştir.

Tablo 5: Çocukların model alma beceri gelişiminin anne ve babanın eğitim durumuna göre kruskal-wallis testi sonuçları

\begin{tabular}{|c|c|c|c|c|c|c|c|}
\hline \multirow{7}{*}{$\underset{Z}{\Xi}$} & Düzey & $\mathbf{n}$ & Sira Ort. & sd & $\chi^{2}$ & $\mathrm{p}$ & Anlamlı Fark \\
\hline & 1. okur yazar değil & 38 & 83,76 & \multirow[t]{6}{*}{4} & \multirow[t]{6}{*}{21,582} & \multirow[t]{6}{*}{.000} & \multirow{6}{*}{$\begin{array}{c}1-3,1-4,1-5,2-4 \\
2-5,3-5,4-5\end{array}$} \\
\hline & 2. okur yazar & 36 & 72,57 & & & & \\
\hline & 3. ilkokul-ortaokul & 65 & 90,67 & & & & \\
\hline & 4. lise & 30 & 102,00 & & & & \\
\hline & 5. üniversite & 13 & 146,46 & & & & \\
\hline & Toplam & 182 & & & & & \\
\hline
\end{tabular}




\begin{tabular}{|c|c|c|c|c|c|c|c|}
\hline \multirow{6}{*}{$\begin{array}{l}\frac{\pi}{\pi} \\
\text { صే }\end{array}$} & 1. okur yazar değil & 3 & 67,17 & 4 & 15,514 & .004 & $2-5,3-5,4-5$ \\
\hline & 2. okur yazar & 10 & 78,45 & & & & \\
\hline & 3. ilkokul-ortaokul & 55 & 85,06 & & & & \\
\hline & 4. lise & 78 & 84,82 & & & & \\
\hline & 5. üniversite & 36 & 121,46 & & & & \\
\hline & Toplam & 182 & & & & & \\
\hline
\end{tabular}

Tablo 5'de çocukların model alma beceri gelişiminin anne ve babanın eğitim durumuna göre farklılaştı̆ğ görülmektedir $\left[\chi^{2}(4)=21,582, \chi^{2}(4)=15,514, p<0.05\right]$. Oluşan bu farklılaşmanın hangi eğitim düzeyleri arasında olduğunu tespit etmek için yapılan Mann Whitney U testi sonuçlarına göre; üniversite mezunu olan annelerin çocukları okur yazar değil, okur yazar, ilkokul-ortaokul ve lise mezunu olan annelerin çocuklarından, lise mezunu olan annelerin çocukları ayrıca okur yazar değil ve okur yazar olan annelerin çocuklarından ve ilkokul-ortaokul mezunu olan annelerin çocukları ayrıca okur yazar olmayan annelerin çocuklarından anlamlı düzeyde pozitif yönde farklı oldukları bulunmuştur. Üniversite mezunu olan babaların çocukları da okur yazar, ilkokul-ortaokul ve lise mezunu olan babaların çocuklarından anlamlı düzeyde pozitif yönde farklı oldukları bulunmuştur.

\section{SONUÇ ve TARTIŞMA}

Bu bölümde araştırmadan elde edilen sonuçlar literatür ışığında tartışılmıştır. Araştırmanın birinci alt probleminde, 4-6 yaş çocukların model alma becerileri ne düzeyde olduğu sorusuna cevap aranmıştır. Yapılan analiz sonucunda, 5 yaş çocukların model oluşturma beceri gelişimleri yüzdelerinin 4 yaş çocuklardan daha yüksek olduğu görülmektedir. Her iki grupta da model oluşturma becerilerinin basitten karmaşığa doğru sıra ile $\mathrm{AB}, \mathrm{AABB}, \mathrm{AAB}, \mathrm{ABC}$ ve kendi modelini oluşturmaya doğru yüzdelik oranlarının düştüğü görülmektedir. Araştırma bulgularına göre, çocukların model oluşturma becerileri 5 yaşında 4 yaşından daha ileri düzeyde olduğu ve modellerin karmaşıklık düzeyine göre her iki grupta da başarının düştügü söylenebilir. Konu ile ilgili araştırmalar incelendiğinde benzer sonuçlara ulaşıldığı görülmektedir. 5-6 yaş çocukların model alma beceri gelişimlerinin incelendiği bu araştırmalarda, Skoumpourdi (2013) 5-6 yaş çocukların model oluşturma becerisine olduklarını bulmuştur. Ancak modelin oluşturulmasında modelin basit ya da karmaşıklığına göre çocukların başarılarında fark bulmuşlardır. Çalışmaya katılan çocukların çoğu AB modelini oluşturma da başarılı bulunurken ABC olan daha karmaşık modeli oluşturmada bu başarılı çocukların yarısı modeli devam ettirebilmişlerdir. Yani kök birim daha karmaşık olduğunda çocukların model oluşturma başarıları da düşmektedir.

Araştırmanın ikinci alt probleminde, 4-6 yaş çocukların model alma becerilerinde cinsiyete göre anlamlı bir şekilde farklılaşma olup olmadığı sorusuna cevap aranmaya çalışılmıştır. Araştırma 
bulguları incelendiğinde çocukların model alma beceri gelişimlerinde cinsiyet durumuna göre anlamlı bir farklılı̆̆ı olmadığı bulunmuştur [ $\mathrm{U}=3797, \mathrm{p}>0.05]$. Bu sonuç, kız ve erkek çocukların model oluşturmada başarı düzeylerinin aynı olduğunu göstermektedir. Başka bir çalışmada bu sonucu destekler niteliktedir. Collins ve Laski (2015) okul öncesi dönemde olan 66 çocukla yaptıkları çalışmada çocukların model oluşturma çalışmalarında kullandıkları problem çözme stratejilerini incelemek amacıyla yaptıkları çalışmada da hem kız hem de erkek çocukların model oluşturma çalışmalarında aynı tür stratejiler kullandıklarını bulmuşlardır. Çocukların model alma becerileri gelişimlerinde cinsiyet açısından farkın olmadığı sonucu ortaya çıkmıştır.

Araştırmanın üçünü alt probleminde 4-6 yaş çocukların model alma becerilerinde yaşa göre anlamlı bir şekilde farklılaşma olup olmadığı sorusuna cevap aranmaya çalışılmıştır. Yapılan analiz sonucunda çocukların model alma beceri gelişimlerinde yaş durumuna göre 5 yaş grubu çocukların anlamlı düzeyde pozitif yönde farklı oldukları bulunmuştur [ $\mathrm{U}=1909,500, \mathrm{p}<0.05]$. Bu sonuçlar doğrultusunda model oluşturma çalışmalarında 5 yaş çocukları 4 yaştakilerden daha başarılı oldukları söylenebilir. Benzer bir sonuç Fyfea, Evans, Matz, Hunt \& Alibali (2017) çalışmalarında da ortaya çıkmıştır. Araştırmacılar çeşitli zorluklarda olan üç tür model oluşturma çalışmasında çocukların (n:36) performanslarını incelemişlerdir. Çalışma bulgularında yaşı büyük olan çocukların küçüklerden daha başarılı oldukları ortaya çıkmıştır. Çocukların yaşlarının artması ile zihinsel gelişimlerinin de arttığı düşünüldüğünde beklenen bir sonuçtur.

Araştırmanın dördüncü alt probleminde 4-6 yaş çocukların model alama becerilerinde okul öncesi eğitime devam etme sürelerine göre anlamlı bir şekilde farklılaşmakta olup olmadığ1 sorusuna cevap aranmaya çalışılmıştır. Araştırma bulguları incelendiğinde çocukların model alma beceri gelişiminin okul öncesi eğitim kurumuna devam etme süresine göre farklılaştığı görülmektedir $\left[\chi^{2}(4)=30,394\right.$, $\mathrm{p}<0.05]$. Yapılan analizler, çocukların okul öncesi eğitim kurumuna devam etme süresi arttıkça model alama beceri gelişimlerinin de yükseldiğini göstermektedir. Papic, Mulligan \& Mitchelmore (2011) çalışmalarında çocukların model alma beceri gelişimleri için uyguladıkları programın etkisini ve bu etkinin kalıcılığını araştırmışlardır. Araştırma bulgularında bir okul öncesi kurumundan programlı eğitim almayan çocukların bile eğer matematik becerilerini geliştirebilecekleri yaşantı fırsatlarına sahip olurlar ise karmaşık olan modelleri oluşturmada başarılı olduklarına işaret çekmişlerdir. Yani küçük yaştaki çocuklara bu becerilerini geliştirebilmeleri için fırsatların sunulması önemlidir. Okul öncesi kurumlarında uygulanan MEB Okul Öncesi Eğitim programında model alma becerileri ile ilgili kazanımlar bulunmaktadır. Bulgularda ortaya çıkan sonucun çocukların 36 aylıktan itibaren bu becerilerini geliştirecekleri firsatlara sahip olmaları okul öncesi eğitim kurumuna devam etme süresi arttıkça model alama becerisindeki gelişimlerinin yükselmesinin sebebi olarak düşünülebilir. 
Araştırmanın beşinci alt probleminde 4-6 yaş çocukların model alama becerilerinde ailelerinin gelir düzeyine göre anlamlı bir şekilde farklılaşma olup olmadığı sorusuna cevap aranmaya çalışılmıştır. Araştırma bulguları incelendiğinde çocukların model alma beceri gelişiminin ailelerin gelir durumuna göre farklılaştığı görülmektedir $\left[\chi^{2}(4)=101.490, \mathrm{p}<0.05\right]$. Yapılan analizler sonucunda ailenin gelir düzeyi arttıkça çocukların model alma beceri gelişimlerinde de artışın olduğu söylenebilir. Yine ailelerin gelir düzeyleri ile çocukların model alma beceri gelişimlerinin incelendiği bir diğer çalışmada Klein ve Starkey (2004) 4-5 yaş arasındaki çocuklara model alma problemi sunmuştur ve orta düzey gelire sahip olan çocukların düşük gelir düzeye sahip olan çocuklardan başarı düzeylerinin daha yüksek olduğu sonucu ortaya çıkmıştır.

Araştırmanın altıncı alt probleminde 4-6 yaş çocukların model alma beceri gelişiminde annebabanın eğitim durumuna göre anlamlı bir şekilde farklılaşma olup olmadığı sorusuna cevap aranmıştır. Yapılan analizler sonucunda çocukların model alma beceri gelişiminin anne ve babanın eğitim durumuna göre farklılaştığ1 görülmektedir $\left[\chi^{2}(4)=21,582, \chi^{2}(4)=15,514, p<0.05\right]$. Araştırma bulguları incelendiğinde, anne ve babanın eğitim düzeyi yükseldikçe çocukların model alma beceri gelişimlerinin de arttığ1 söylenebilir. Ailenin eğitim durumu, matematiğe olan bakış açılarını ve tutumlarını, çocuğa matematiksel etkinliklerin kalitesini etkilemektedir (Clements \& Sarama, 2007; Musun-Miller \& Blevins-Knabe, 1998).

\section{ÖNERİLER}

1. Öğretmenlere ve ebeveynlere okul öncesi dönemde model alma beceri gelişimi açısından kız ve erkek çocukların farklılık göstermedikleri hakkında bilgiler verilebilir

2. Ailelere, çocuklarının daha erken yaşlarda okul öncesi kuruma devam etmesinin önemi konusunda bilgilendirme çalışmaları düzenlenebilir.

3. Eğitim düzeyi düşük ailelerin, okul öncesi eğitim kurumuna devam edemeyen çocukları için evde kaliteli matematik etkinlikleri yapabilmelerini destekleyecek proje çalışmaları yürütülebilir.

4. Okul öncesi öğretmenlerin sınıflarındaki düşük gelir düzeyine sahip çocukların model alma beceri gelişimlerini desteklemeleri için en az iki eğitim-öğretim yllı uygulayabilecekleri sistemli bir matematik eğitim programı hazırlanabilir.

\section{KAYNAKÇA}

ACARA (Australian Curriculum, Assessment and Reporting Authority), (2010). Australian curriculum: $\quad$ Mathematics. 28.03 .2018 tarihinde http://www.australiancurriculum.edu.au/Mathematics/Curriculum/F-10 adresinden erişildi. 
Aktaş Arnas, Y., Deretarla Gül, E. \& Sığırtmaç, A. (2003). "48-86 Ay çocuklar için sayı ve işlem kavramları testini’ nin geçerlik ve güvenirlik çalışması”. Çukurova Üniversitesi Sosyal Bilimler Enstitüsü Dergisi, 12(12), 147-157.

Aslan, D. \& Aktaş Arnas, Y. (2007). "Okul öncesi eğitim materyallerinde geometrik şekillerin sunuluşuna ilişkin içerik analizi”. Çukurova Üniversitesi Sosyal Bilimler Enstitüsü Dergisi, 16(1), 69-80.

Avı, K. (2015). "Okul Öncesi Eğitimi Alan 48-66 Ayllk Cocuklarn Matematik Becerilerinin Bą? Değiskeenler Açısından Incelenmesi”. (Yayınlanmamıș Yüksek Lisans Tezi), Onsekiz Mart Üniversitesi, Eğitim Bilimleri Enstitüsü, Çanakklale

Bolat, Y. E. \& Sı̆̆ırtmaç, D. A. (2006). "Sayı ve işlem kavramı kazanımında müzikli oyunların etkisi”. Ege Eğitim Dergisi, (7) 2, 43-56.

Bulut, M. S. \& Tarım, K. (2006). “Okul öncesi öğretmenlerinin matematik ve matematik öğretimine ilişkin alg1 ve tutumlar1”. Çukurova Üniversitesi Eğitim Fakültesi Dergisi, 3(32), 152-164

Clements, D.H. \& Sarama, S. (2007a). "Early childhood mathematics learning" Secont handbook of research on mathematics teaching and learning", Farnk K. Lester (Ed.),US, Information Age Publishing.

Collins, M. A., \& Laski, E. V. (2015). "Preschoolers' strategies for solving visual pattern tasks". Early Childhood Research Quarterly, 32, 204-214.

Çelik, M. (2017), "Examination of the relationship between the preschool teachers' attitudes towards mathematics and the mathematical development in 6-year-old preschool children", Journal of Education and Learning, 6(4) 49-56

Çelik, M. (2017) “Okulöncesi öğretmenlerinin erken matematik eğitimine ilişkin tutumları”, İnönü University Journal of the Faculty of Education 18 (1) 58-70

Depps (2001). Interdisciplinary Greek Curriculum. 28.03.2018 tarihinde http://www.pischools.gr/programs/depps. Accessed 18 October 2001. Adresinden erişildi.

English, L.D. \& Watters, J.J. (2005). "Mathematical modelling in the early school years". Mathematics Education Research Journal, 16(3) 58-79.

Erdoğan, S. \& Baran, G. (2006). "Erken matematik yeteneği testi-3 (tema-3)'ün 60-72 aylar arasında olan çocuklar için uyarlama çalışması”. Çağdaş Ë̆itim, 332, 32-38.

Fyfea, E.R., Evans, J.L., Matz, E.L., Hunt, K.M \& Alibali, M.W., (2017). "Relations between patterning skill and differing aspects of early mathematics knowledge", Cognitive Development, $44,1-17$.

Kesicioğlu, O. S. (2013). “Okul öncesi dönem çocuklarının matematiksel örüntü becerilerinin incelenmesi”. Akdeniz Ë̆itim Arastırmalar Dergisi, 13, 19-26.

Kidd, J. K., Pasnak, R., Gadzichowski, K. M., Gallington, D. A., McKnight, P., Boyer, C. E., \& Carlson, A.. (2014). "Instructing first-grade children on patterning improves reading and mathematics". Early Education \& Development, 25, 134-151. http://dx.doi.org/10.1080/10409289.2013.794448 
Klein, A. \& Starkey, P. (2004). "Fostering preschool children's mathematical development: Finding from the Berkeley math readiness Project". In D. H. Clements, J. Sarama, \& A.M. DiBiase (Eds.) Engaging young children in mathematic: Standards for early childhood mathematics education (pp. 343-360) Mahwah, NJ: Erlbaum.

Musun-Miller, L. \& Blevins-Knabe, B. (1998). "Adults' beliefs about children and mathematics: how important is it and how do children learn about it?" Early Development and Parenting, 7, 191-202.

NCTM (National Council of Teachers of Mathematics) (2000). Principles and Standards for School Mathematics. Reston, VA: NCTM.

Papic, M.M., Mulligan, J.T. \& Michael C. Mitchelmore, M.C.(2011). "Assessing the development of preschoolers' mathematical patterning". Journal for Research in Mathematics Education, 42(3) 237- 269.

Pekince, P. \& Dağlıoğlu, H. E. (2017). “Sayma ilkeleri testi’nin geçerlik ve güvenirlik çalışması”. İlkögretim Online, 16(2), 765-781

Rittle-Johnson, B., Fyfe, E. R., Hofer, K., \& Farran, D. (2016). "Early math trajectories: lowincome children's mathematics knowledge from age 4 to 11". Child Development. 88(5), $1727-1742$.

Skoumpourdi, C. (2013). "Kindergartners' performance levels on patterning". International Journal For Mathematics In Education, HMS i JME, 5, 108-131.)

Taştepe, T. \& Temel, Z. F. (2013). "Erken çocukluk dönemi fen ve matematik eğitimi içerik standartları değerlendirme araçlarının geliştirilmesi (geçerlik ve güvenirlik çalışmaları)". Kastamonu Ë̈itim Dergisi, 21(4) (Özel Say1), 1625-1640.

Tsamir, P., Tirosh, D., Levenson, E.S., Barkai, R. \& Tabach, M. (2017) "Repeating patterns in kindergarten: findings from children's enactments of two activities". Educational Studies in Mathematics, 96(1), 83-99

Yılmaz, B. (2015). “48-60 Aylık Çocuklar İçin Erken Sayı Değerlendirme Ölçeğı’nin Geģerlik Güvenirlik Calıs̆ması". (Yayımlanmamıs Yüksek Lisans Tezi). Adnan Menderes Üniversitesi Sosyal Bilimler Enstitüsü, Aydın

Waters, J. (2004). Mathematical patterning in early childhood settings. In I. Putt, R. Faragher, \& M. Mclean (Eds.), Mathematics Education for the Third Millennium: Towards 2010 (Proceedings of the 27th annual conference of the Mathematics Education Research Group of Australasia, Townsville, Vol. 2, 565- 572). Sydney: MERGA. 